\title{
In Vitro Evaluation of Grass and Legume/Browse Species Grazed by West African Dwarf Goats in South-Western Nigeria
}

\author{
G.O. Tona ${ }^{1 *}$, F.O. Ogunleke ${ }^{2}$, A.O. Asaolu ${ }^{1}$, A.O. Yusuf ${ }^{1}$, E.J. Olasusi ${ }^{1}$ \\ ${ }^{1}$ Department of Animal Production and Health, Ladoke Akintola University of Technology, PMB 4000, \\ Ogbomoso, Oyo State, Nigeria \\ ${ }^{2}$ Federal College of Animal Health and Production Technology, Moor Plantation, Apata, Ibadan, Oyo State, \\ Nigeria \\ Corresponding Author: G.O. Tona
}

\begin{abstract}
Four grass species (Panicum maximum, Imperata cylindrica, Axonopus fissifolius and Brachiaria decumbens) and three legume/browse species (Leucaena leucocephala, Centrosema pubescens, and Gliricidia sepium) were evaluated for proximate composition and in vitro gas production characteristics. The completely randomized design with four grass species and three legume/browse species, each in triplicates was employed. The dry matter of the grass species ranged between 79.38 and 89.95\%, while that of legume/browse species ranged from 85.00 to $93.38 \%$. The crude protein contents of the grasses ranged from 5.68 to $8.72 \%$ and the legumes from 16.02 to $28.86 \%$. Other ranges of values were for crude fibre, 18.34 to $24.32 \%$ in the grasses and 12.16 to $61.41 \%$ in the legume/browse species. Gas production $(23.00-54.00 \mathrm{ml} / 200 \mathrm{mg} \mathrm{DM})$ at $24 \mathrm{~h}$ incubation, potential gas production $(a+b)$ also $(23.00-54.00 \mathrm{ml} / 200 \mathrm{mg} D \mathrm{DM})$, metabolizable energy $(\mathrm{ME})$ $(6.01-7.07 \mathrm{MJ} / \mathrm{kg} \mathrm{DM})$, organic matter digestibility $(O M D)(44.53-78.91 \%)$ and short chain fatty acids (SCFA) $(0.49-1.23 \mu \mathrm{mol})$ were observed. These values were higher in the legume/browse than in the grass species. In conclusion, the observed nutritive values of the forages understudied have shown that they could be beneficial for improved goat production in Nigeria.
\end{abstract}

Keywords: Proximate composition, in vitro gas production, forages, goat.

\section{Introduction}

Ruminant production is one of the ways of reducing animal protein deficiency in most developing countries. In most of these countries, the recommended minimum daily animal protein intake of $35 \mathrm{~g}$ per head was difficult to attain due to low levels of livestock production (FAO, 2008). The scarcity of forage for ruminants, particularly during the dry season result in weight loss, reduced meat and milk production and sometimes leads to high mortality of animals. The best solution to this problem could be to intensify research into the sourcing of cheaper and available feedstuffs that can meet the nutritional requirement of ruminants. The native pasture is known to be the most widely available low cost feed for ruminants in the tropics. However, majority of tropical livestock have access only to limited quantities of pastures with relatively low nutritive value. Also, both milk yield and growth of ruminants are largely limited by forage quality which is reflected in low feed intake and digestibility. Kamalak (2005) stated that tree and shrub leaves are important component of sheep and goats diets. However, there can only be improvement in the productivity of these ruminants when the nutritional qualities of these forages are assessed and improved upon.

Ajayi and Babayemi (2008) made a comparative in vitro evaluation of sole Panicum maximum with Stylosanthes guianensis, Lablab purpureus, Centrosema pubescens and Aeschynomene histrix using female West African Dwarf does. They observed a crude protein content of $7.63 \%$ for the sole Panicum maximum grass, and for the Panicum maximum with legume mixtures, the crude protein ranged from 18.05 to $23.29 \%$. Ether extract was $2.76 \%$ in sole Panicum maximum grass but ranged between 8.42 and $12.66 \%$ in the Panicum maximum with legume mixtures. The ash content was $6.78 \%$ in sole $P$. maximum grass but increased to the range of 8.42 to $12.66 \%$ for the mixtures. The potential gas production, 'b' value from the insoluble fraction of the sole $P$. maximum was $16.90 \mathrm{ml} / \mathrm{g}$ DM while the ' $\mathrm{b}$ ' values ranged from 14.55 to $22.10 \mathrm{ml} / \mathrm{g} \mathrm{DM}$ in the Panicum maximum with legume mixtures. Thus Ajayi and Babayemi (2008) found out that there were increased proximate composition and in vitro gas production values in the grass/ legume mixtures than sole grass. Other earlier researchers, Evitayani et al. (2004) studied the nutritive values of tropical forages commonly used as ruminant feeds in North Sumatra, Indonesia. They observed that crude protein content ranged from 6.6 to $16.2 \%$ in grass and from 17.5 to $29.1 \%$ in legumes. The organic matter digestibility of grass ranged from 51.9 to $64.4 \%$ while in legumes the values ranged from 65.2 to $72.0 \%$. The metabolizable energy content of grass varied from 
6.4 to $9.3 \mathrm{MJ} / \mathrm{kg}$ and from 6.5 to $8.3 \mathrm{MJ} / \mathrm{kg}$ for legumes. Thus the crude protein content and organic matter digestibility values were higher for legumes than in the grass species studied. Odeyinka (2001) stated that since ruminants cannot meet their maintenance needs on grass alone, leguminous plants such as Leucaena leucocephala, Centrosema pubescens, and Gliricidia sepium can be fed in combination with grass especially during the dry season.

The aim of this study is to assess proximate composition and in vitro gas production characteristics of four indigenous grass and three legume/browse species grazed by West African Dwarf goats in South-Western Nigeria. This could serve as preliminary investigation for studying other grass and legume/browse mixtures.

\subsection{Collection of forages}

\section{Materials And Methods}

Samples of four grass species (Panicum maximum, Imperata cylindrica, Axonopus fissifolius and Brachiaria decumbens) and three legume/browse species (Leucaena leucocephala, Centrosema pubescens, and Gliricidia sepium) were collected during the dry season in January 2014. They were harvested in the environment of the Ladoke Akintola University of Technology, Ogbomoso, Nigeria. The leaves were defoliated, oven dried at $105^{\circ} \mathrm{C}$ to a constant weight for 24 hours for dry matter determination. Another set of the leaf samples were oven dried at $65^{\circ} \mathrm{C}$ for 48 hours to a constant weight, milled to pass through $1.0 \mathrm{~mm}$ sieve and stored in air tight containers pending laboratory analysis.

\subsection{Chemical analysis}

Ash content of samples was determined by igniting the samples in a muffle furnace at $600^{\circ} \mathrm{C}$ for 8 hours. Nitrogen $(\mathrm{N})$ content of the forages was determined by the standard Kjeldahl method, also crude fibre and ether extract were determined according to the methods of AOAC (2005). Crude protein was calculated ( $\mathrm{N} \mathrm{x}$ $6.25)$ and NFE was also calculated $(100-(\% \mathrm{CP}+\% \mathrm{CF}+\% \mathrm{EE}+\%$ Ash $+\%$ moisture $)$. Samples were determined in triplicates.

\subsection{In vitro gas production experiment}

Rumen fluid was obtained with suction tube from three female WAD goats that were previously fed (two days prior) concentrate feed (40\% maize, $10 \%$ wheat offal, $10 \%$ palm kernel cake, $20 \%$ groundnut cake, $5 \%$ soybean meal, $10 \%$ dried brewer grain, $1 \%$ common salt, $3.75 \%$ oyster shell and $0.25 \%$ fish meal). In addition, foliages of Panicum maximum, Imperata cylindrica, Axonopus fissifolius and Brachiaria decumbens grass species and three legume/browse species Leucaena leucocephala, Centrosema pubescens, and Gliricidia sepium were fed to the goats (the feed was about 5\% of their body weights). Two hundred (200) $\mathrm{mg}$ of diet samples (containing the experimental grass and legume/ browse species) labelled (G1- G4) and (L1-L3) were placed in triplicates in $120 \mathrm{ml}$ calibrated syringes. About $30 \mathrm{ml}$ inoculums containing (cheese-cloth) strained rumen liquor and buffer solutions $(1: 4 \mathrm{v} / \mathrm{v})$ under constant flushing with $\mathrm{CO}_{2}$ were incubated. The liquor was collected into pre-warmed thermos flasks. Ingredients of the buffer solution were $9.8 \mathrm{NaHCO}_{3}+2.77 \mathrm{Na}_{2} \mathrm{HPO}_{4}$ $+0.57 \mathrm{KCl}+0.47 \mathrm{NaCl}+2.16 \mathrm{MgSO}_{4} \cdot 7 \mathrm{H}_{2} \mathrm{O}+0.16 \mathrm{CaCl}_{2} \cdot 2 \mathrm{H}_{2} \mathrm{O}$. Incubation was carried out at $3,6,9,12,15$, 18,21 and $24 \mathrm{~h}$ at $39^{\circ} \mathrm{C}$. At post incubation period, the gas production was measured at $3,6,9,12,15,18,21$ and $24 \mathrm{~h}$. Average volumes of gas produced from the blanks were deducted from the volume of gas produced per sample. (The blanks contained only the inoculums and buffer). Rates and extent of gas production were determined for each substrate using the linear equation: $\mathrm{Y}=\mathrm{a}+\mathrm{b}\left(1-\mathrm{e}^{-\mathrm{ct}}\right)$ (as described by Orskov and McDonald (1979). Where: $\mathrm{Y}=$ volume of gas produced at time ' $\mathrm{t}$ '; $\mathrm{a}=$ intercept (gas produced from the soluble fraction); $b=$ potential gas production $(\mathrm{ml})$ from the insoluble fraction; $\mathrm{c}=$ gas production rate constant $\left(\mathrm{h}^{-1}\right)$ for the insoluble fraction (b); $\mathrm{t}=$ incubation time. Metabolizable energy $(\mathrm{ME}, \mathrm{MJ} / \mathrm{kg} \mathrm{DM})$ was calculated as $\mathrm{ME}=$ $2.20+0.136 \mathrm{GV}+0.057 \mathrm{CP}+0.0029 \mathrm{CF}$ (Menke and Steingass, 1988). Organic matter digestibility (OMD \%) was estimated as OMD $=14.88+0.889 \mathrm{GV}+0.45 \mathrm{CP}+0.651 \mathrm{XA}$ (Menke and Steingass, 1988). Short chain fatty acids $(\mathrm{SCFA})=0.0239 \mathrm{GV}-0.0601$ (Getachew et al., 1999). Where GV, CP, CF and XA are total gas volume, crude protein, crude fibre and ash respectively of the incubated samples.

\subsection{Statistical analysis}

Data from the experiment were subjected to one way analysis of variance (ANOVA) procedure of SAS (2000), using the completely randomized design. Significant means were ranked using the Duncan's multiple range test of the same package. Mean differences were considered significant at $\mathrm{P}<0.05$. 


\section{Results And Discussion \\ 3.1 Proximate composition of grass and legume/browse species \\ 3.1.1 Proximate composition of the grass species}

Table 1 shows the proximate composition of the grass and legume/browse species. The dry matter contents of the four grass species ranged from $79.38 \%$ for Panicum maximum to $89.95 \%$ for Imperata cylindrica. The crude protein content of the grasses were 5.68\% for Brachiaria decumbens, $7.30 \%$ for Axonopus fissifollius, $7.91 \%$ for Panicum maximum and $8.72 \%$ for Imperata cylindrica. These values are comparable to the values of $7.9 \%$ crude protein of $P$. maximum (Babayemi, 2007), $7.63 \%$ crude protein of P. maximum (Ajayi and Babayemi, 2008), 9.55\% crude protein of P. maximum (Yusuf et al., 2013), 9.40\% crude protein of $P$. maximum (Asaolu et al., 2014) and $10.47 \%$ crude protein of P. maximum (Tona, 2014). The crude protein levels of $(5.68-8.72 \%)$ for the grass species in this study were close to the $8 \%$ crude protein required to provide the minimum ammonia levels required by micro-organisms for optimum rumen activity (Norton, 1995). It however did not meet the required range of 11.0 to $13.0 \%$ crude protein required to supply adequate protein for maintenance and moderate growth in goats (Poppi and McLennan, 1995). Since the crude protein contents of the grasses in the current study might not be adequate to meet the requirement for ruminants, proper supplementation with legume/browse species or concentrate diets could enhance ruminant performance as demonstrated in the research of Tona (2014). Tona (2014) investigated ruminant diet combinations of $P$. maximum with Gliricidia sepium and cassava peels.

\subsubsection{Proximate composition of the legume/browse species}

Dry matter contents of the legume/browse species ranged between 85.00 and $93.38 \%$. The crude protein contents of the legume/browse species ranged from 16.02 in C. pubescens to $28.86 \%$ in L. leucocephala, and this range was close to the crude protein contents of $16.0 \%$ in C. pubescens, $25.7 \%$ in G. sepium and $27.6 \%$ in L. leucocephala reported by Babayemi (2007). It has been observed that the legume/browse species contained higher crude protein content than in the grass species. Similar findings were made in the works of Evitayani et al. (2004), Babayemi (2007), Ajayi and Babayemi (2008) and Asaolu et al. (2014). Also, the crude protein contents of the legume/browse species in the current study were well above the minimum requirement of 11.0 to 13.0\% recommended for maintenance and moderate growth of goats (Poppi and McLennan, 1995). Other ranges of values observed in the present study were, 12.16 to $61.41 \%$ of crude fibre, 2.60 to $8.45 \%$ of ether extract and 4.10 to $10.52 \%$ of ash, for both the grass and legume/browse species. These are close to the ranges of $56.8-$ $74.1 \%$, crude fibre; $2.1-12.5 \%$, ether extract; and $3.6-10.8 \%$ ash found in the study of Babayemi (2007), for grasses, legumes and browse plants. The high crude fibre content observed in C. pubescens (61.41\%), in this study is favourable for the environmental conditions of the rumen which is normally in favour of the fibrolytic micro-organisms which aid the degradation of high fibre diets in contrast to the negative effects of concentrates high in carbohydrates (Nouala et al., 2006).

\begin{tabular}{|c|c|c|c|c|c|c|}
\hline Composition (\%) & DM & $\mathrm{CP}$ & $\mathrm{CF}$ & EE & Ash & NFE \\
\hline \multicolumn{7}{|l|}{ Grass species } \\
\hline Panicum maximum & 79.38 & 7.91 & 23.58 & 4.21 & 5.82 & 49.86 \\
\hline Imperata cylindrica & 89.95 & 8.72 & 18.34 & 5.74 & 8.11 & 50.04 \\
\hline Axonopus fissifolius & 80.65 & 7.30 & 24.32 & 3.85 & 6.37 & 47.51 \\
\hline Brachiaria decumbens & 81.75 & 5.68 & 22.04 & 8.45 & 5.34 & 46.74 \\
\hline \multicolumn{7}{|l|}{ Legume/browse species } \\
\hline Leucaena leucocephala & 93.38 & 28.86 & 12.16 & 5.67 & 9.68 & 37.01 \\
\hline Centrosema pubescens & 85.00 & 16.02 & 61.41 & 2.60 & 4.10 & 0.87 \\
\hline Gliricidia sepium & 91.02 & 18.55 & 21.18 & 2.64 & 10.52 & 38.13 \\
\hline
\end{tabular}

$\mathrm{DM}=$ Dry matter, $\mathrm{CP}=$ Crude protein, $\mathrm{CF}=$ Crude fibre, $\mathrm{EE}=$ Ether extract, $\mathrm{NFE}=$ Nitrogen free extract

\subsection{In vitro gas production of grass and legume/browse species for a period of 24 hour}

\subsubsection{In vitro gas production of grass species}

The gas production during the 24 hour period of incubation is presented in Table 2. All the values of the gas production in the grasses were significant $(\mathrm{P}<0.05)$. At the 24 hours of incubation, the gas production in the grasses ranged between $24.00 \mathrm{ml} / 200 \mathrm{mg}$ (I. cylindrica) and $32.00 \mathrm{ml} / 200 \mathrm{mg}$ (P. maximum). In earlier studies, gas production values of $5 \mathrm{ml} / 200 \mathrm{mg}$ DM (Tona, 2014), $40 \mathrm{ml} / 200 \mathrm{mg}$ DM (Babayemi, 2007; Asaolu et al., 2014) at $24 \mathrm{~h}$ of incubation period were reported for P. maximum grass.

\subsubsection{In vitro gas production of legume/browse species}

The in vitro gas production of the legume and browse plants ranged from $23.00 \mathrm{ml} / 200 \mathrm{mg} \mathrm{DM}(G$. sepium) to $54.00 \mathrm{ml} / 200 \mathrm{mg} \mathrm{DM}$ in (C. pubescens). The values observed in this research are comparable with the net gas volume of $C$. pubescens $(49.7 \mathrm{ml} / 200 \mathrm{mg} \mathrm{DM})$, G. sepium $(59.7 \mathrm{ml} / 200 \mathrm{mg} \mathrm{DM})$ and L. leucocephala $41.0 \mathrm{ml} / 200 \mathrm{mg} \mathrm{DM}$ ) observed by Babayemi (2007). Asaolu et al. (2014) reported gas production volumes of

DOI: 10.9790/2380-1007017075 $\quad$ www.iosrjournals.org $\quad 72 \mid$ Page


$25.67 \mathrm{ml} / 200 \mathrm{mg}$ DM in G. sepium and $18.00 \mathrm{ml} / 200 \mathrm{mg}$ DM in L. leucocephala. Ajayi and Babyemi (2008) observed lower gas production volume of $17.50 \mathrm{ml} / 200 \mathrm{mg}$ DM in C. pubescens. Fieves et al. (2005) reported that in vitro gas production is comparable with feed digestibility, so that the higher the gas production, the higher the digestibility. The differences in the values of gas production volumes could be due to differences in the presence of secondary metabolites (anti-nutrients) as were explained by Babayemi (2007) and Ajayi and Babayemi (2008). In this study, the highest $(\mathrm{P}<0.05)$ gas production observed for Centrosema pubescens $(54.00$ $\mathrm{ml} / 24 \mathrm{~h})$ and Leucaena leucocephala $(50.33 \mathrm{ml} / 24 \mathrm{~h})$ could be due to their high CP contents. This could have enhanced microbial multiplication in the rumen fluid, which in turn could have determined the extent of their fermentation. This is supported in the research of Sommart et al. (2000), which suggested that gas volume is a good parameter from which to predict in vitro digestibility, fermentation end product and microbial protein synthesis of a substrate by rumen microbes in the in vitro system. In this study, the lower range of gas production from the grass species $(24.00-32.00 \mathrm{ml})$ could signify lower fermentation potential than in the legume/browse species $(23.00-54.00 \mathrm{ml})$. Babayemi and Bamikole (2006) explained that gas production from protein fermentation was relatively higher compared to carbohydrate fermentation. This confirms that the feeding of small ruminants with grass needs to be supplemented with legume/browse forage for efficient productivity.

Table 2 In vitro gas production volumes ( $\mathrm{ml} / 200 \mathrm{mg}$ sample) of grass and legume/browse species for a period

\begin{tabular}{|c|c|c|c|c|c|c|c|c|}
\hline $\begin{array}{l}\text { Incubation } \\
\text { period }(\mathrm{h})\end{array}$ & 3 & 6 & 9 & 12 & 15 & 18 & 21 & 24 \\
\hline \multicolumn{9}{|l|}{ Grass } \\
\hline I. cylindrical & $2.67^{\mathrm{b}}$ & $5.33^{\mathrm{c}}$ & $10.00^{\mathrm{b}}$ & $14.67^{\mathrm{b}}$ & $19.67^{\mathrm{b}}$ & $23.00^{\mathrm{b}}$ & $23.67^{\mathrm{c}}$ & $24.00^{\mathrm{c}}$ \\
\hline A. fissifolius & $3.00^{\mathrm{a}}$ & $7.00^{\mathrm{a}}$ & $12.00^{\mathrm{a}}$ & $16.33^{\mathrm{a}}$ & $19.00^{\mathrm{b}}$ & $21.33^{c}$ & $22.67^{\mathrm{c}}$ & $25.00^{\mathrm{c}}$ \\
\hline B. decumbens & $2.33^{c}$ & $5.33^{\mathrm{c}}$ & $8.67^{\mathrm{c}}$ & $14.67^{\mathrm{b}}$ & $20.67^{b}$ & $23.00^{\mathrm{b}}$ & $27.00^{\mathrm{b}}$ & $29.00^{b}$ \\
\hline L. leucocephala & $8.67^{\mathrm{a}}$ & $16.00^{\mathrm{a}}$ & $24.00^{\mathrm{a}}$ & $31.67^{\mathrm{a}}$ & $36.00^{\mathrm{a}}$ & $38.67^{\mathrm{a}}$ & $44.00^{\mathrm{a}}$ & $50.33^{\mathrm{a}}$ \\
\hline C. pubescens & $6.33^{\mathrm{b}}$ & $15.00^{\mathrm{b}}$ & $23.33^{\mathrm{a}}$ & $29.67^{\mathrm{b}}$ & $35.00^{\mathrm{a}}$ & $38.67^{\mathrm{a}}$ & $45.67^{\mathrm{a}}$ & $54.00^{\mathrm{a}}$ \\
\hline G. sepium & $3.33^{c}$ & $6.00^{\mathrm{c}}$ & $9.33^{\mathrm{b}}$ & $14.67^{\mathrm{c}}$ & $17.33^{\mathrm{b}}$ & $19.67^{b}$ & $23.00^{\mathrm{b}}$ & $23.00^{\mathrm{b}}$ \\
\hline$\pm \mathrm{SEM}$ & 1.55 & 3.18 & 4.78 & 5.36 & 6.06 & 6.33 & 7.29 & 9.78 \\
\hline
\end{tabular}

\subsection{In vitro gas production characteristics of grass and legume/browse species \\ 3.3.1 In vitro gas production characteristics of grasses}

The in vitro gas production characteristics are shown in Table 3. In vitro gas production characteristics of grasses were found to be significantly different $(\mathrm{P}<0.05)$ in all the four grass species. The volume of gas produced at time " $\mathrm{t}$ ", that is the $(\mathrm{Y})$ values ranged from 13.67 to $23.33 \mathrm{ml} / 200 \mathrm{mg} \mathrm{DM}$, while the ' $\mathrm{a}+\mathrm{b}$ ' values ranged from 24.00 to $32.00 \mathrm{ml} / 200 \mathrm{mg} \mathrm{DM}$. The $\mathrm{Y}$ value for $P$. maximum was 23.33 and ' $\mathrm{a}+\mathrm{b}$ ' was 32.00 $\mathrm{ml} / 200 \mathrm{mg}$ DM in this study. Other researchers observed lower $\mathrm{Y}$ and ' $\mathrm{a}+\mathrm{b}$ ' values for P.maximum. Ajayi and Babayemi (2008) recorded the volume of gas production of $Y=6.52$ and ' $a+b$ ' $=18.30 \mathrm{ml} / 200 \mathrm{mg} \mathrm{DM}$ for P.maximum. Tona (2014) observed $\mathrm{Y}=10.00$ and ' $\mathrm{a}+\mathrm{b}$ ' $=6.00 \mathrm{ml} / 200 \mathrm{mg}$ DM for P.maximum. Asaolu et al. (2014) reported $\mathrm{Y}=9.00$ and ' $\mathrm{a}+\mathrm{b}$ ' $=17.67 \mathrm{ml} / 200 \mathrm{mg}$ DM for sole P.maximum. The differences in the ' $\mathrm{Y}$ ' and ' $\mathrm{a}+\mathrm{b}$ ' values were probably due to the differences in the crude fibre percentages of their proximate compositions. Babayemi et al. (2004) stated that there are many factors that may determine the amount of gas to be produced during fermentation, depending on the nature and level of fibre, the presence of secondary metabolites and potency of the rumen liquor used for incubation. They also explained that it was only possible to attain potential gas production of a feedstuff if the donor animal from which rumen liquor used for incubation was collected got their nutrients requirement met.

\subsubsection{In vitro gas production characteristics of legume/browse species}

The in vitro gas production characteristics were also observed to vary significantly $(\mathrm{P}<0.05)$ in the three legume/browse plants. The values of the volumes of gas produced at time ' $t$ ' ( $\mathrm{Y}$ ) and ' $\mathrm{a}+\mathrm{b}$ ' values ranged from 14.67 and $23.00 \mathrm{ml} / 200 \mathrm{mg} \mathrm{DM} \mathrm{(G.} \mathrm{sepium),} 24.67$ and $50.33 \mathrm{ml} / 200 \mathrm{mg} \mathrm{DM}$ (L. leucocephala) and 19.33 and $54.00 \mathrm{ml} / 200 \mathrm{mg} \mathrm{DM}($ C. pubescens). Ajayi and Babayemi (2008) found ' $\mathrm{Y}$ ' and ' $\mathrm{a}+\mathrm{b}$ ' values of 16.48 and $25.34 \mathrm{ml} / 200 \mathrm{mg}$ DM (C. pubescens). In the research of Asaolu et al. (2014), 8.67 and $25.00 \mathrm{ml} / 200 \mathrm{mg}$ DM were observed for G. sepium. Also for L. leucocephala, ' $\mathrm{Y}$ ' and ' $\mathrm{a}+\mathrm{b}$ ' values were 10.00 and $18.00 \mathrm{ml} / 200 \mathrm{mg}$ DM. Differences could be attributed to the reasons outlined above for grasses. 
In Vitro Evaluation of Grass and Legume/Browse Species Grazed by West African Dwarf Goats in

Table 3 In vitro gas production characteristics of grass and legume/browse species

\begin{tabular}{|c|c|c|c|c|}
\hline Treatments & $\mathrm{Y}$ & $\mathrm{b}$ & $a+b$ & $\mathrm{c}$ \\
\hline \multicolumn{5}{|l|}{ Grass } \\
\hline P. maximum & $23.33^{\mathrm{a}}$ & $29.67^{\mathrm{a}}$ & $32.00^{\mathrm{a}}$ & $0.10^{\mathrm{a}}$ \\
\hline I. cylindrical & $15.33^{b}$ & $21.33^{c}$ & $24.00^{\mathrm{c}}$ & $0.08^{\mathrm{b}}$ \\
\hline A. fissifolius & $13.67^{b}$ & $22.00^{\mathrm{c}}$ & $25.00^{\mathrm{c}}$ & $0.07^{\mathrm{b}}$ \\
\hline B. decumbens & $14.67^{b}$ & $26.67^{b}$ & $29.00^{\mathrm{b}}$ & $0.05^{\mathrm{c}}$ \\
\hline \pm SEM & 2.22 & 1.98 & 1.85 & 0.01 \\
\hline \multicolumn{5}{|l|}{ Legume/browse } \\
\hline L. leucocephala & $24.67^{\mathrm{a}}$ & $41.67^{b}$ & $50.33^{b}$ & $0.05^{\mathrm{b}}$ \\
\hline C. pubescens & $19.33^{b}$ & $47.67^{\mathrm{a}}$ & $54.00^{\mathrm{a}}$ & $0.04^{\mathrm{c}}$ \\
\hline G. sepium & $14.67^{\mathrm{c}}$ & $19.67^{\mathrm{c}}$ & $23.00^{\mathrm{c}}$ & $0.08^{\mathrm{a}}$ \\
\hline \pm SEM & 2.89 & 8.51 & 9.78 & 0.01 \\
\hline
\end{tabular}

3.4 In vitro metabolizable energy (ME), organic matter digestibility (OMD) and short chain fatty acids (SCFA) levels of grass and legume/browse species

3.4.1 Metabolizable energy (ME), organic matter digestibility (OMD) and short chain fatty acids (SCFA) of grass species

Table 4 shows the in vitro metabolizable energy (ME), organic matter digestibility (OMD) and short chain fatty acids (SCFA) of grass and legume/browse species. The values observed were all significantly $(\mathrm{P}<0.05)$ different. The values of ME, OMD and SCFA in the grasses ranged as follows: 6.01 to $7.07 \mathrm{MJ} / \mathrm{kg} \mathrm{DM}$ of ME, 44.53 to $50.67 \%$ of OMD and 0.51 to $0.70 \mu \mathrm{mol}$ of SCFA. The highest values found were $7.07 \mathrm{MJ} / \mathrm{kg}$ $\mathrm{DM}$ of ME, $50.67 \%$ of OMD and $0.70 \mu \mathrm{mol}$ of SCFA in P. maximum. Lower values were reported in earlier research works; Ajayi and Babayemi (2008) observed 2.94 MJ/kg DM of ME, 29.15\% OMD and $0.06 \mu \mathrm{mol}$ of SCFA for sole P. maximum. Tona (2014) reported $3.87 \mathrm{MJ} / \mathrm{kg}$ DM of ME, $31.23 \%$ OMD and $0.08 \mu \mathrm{mol}$ of SCFA for sole $P$. maximum. Asaolu et al. (2014) obtained predicted values of $5.24 \mathrm{MJ} / \mathrm{kg}$ DM of ME, $41.58 \%$ $\mathrm{OMD}$ and $0.36 \mu \mathrm{mol}$ of SCFA for sole P. maximum.

3.4.2 Metabolizable energy (ME), organic matter digestibility (OMD) and short chain fatty acids (SCFA) of legume/browse species

Among the legume/browse species, the highest $(\mathrm{P}<0.05)$ values were observed for $C$. pubescens legume forage with $10.73 \mathrm{MJ} / \mathrm{kg}$ DM of ME, $78.91 \%$ OMD and $1.23 \mu \mathrm{mol}$ of SCFA. Next was for G. sepium browse plant with $10.64 \mathrm{MJ} / \mathrm{kg}$ DM of ME, $72.76 \%$ OMD and $1.15 \mu$ mol of SCFA. The lowest values of 6.45 $\mathrm{MJ} / \mathrm{kg}$ DM of ME, $50.13 \%$ OMD and $0.49 \mu \mathrm{mol}$ of SCFA were recorded for L. leucocephala. Lower values were reported in the study of Asaolu et al. (2014) as follows: $6.86 \mathrm{MJ} / \mathrm{kg}$ DM of ME, $52.35 \%$ OMD and 0.54 $\mu \mathrm{mol}$ of SCFA for Gliricidia sepium; and for Leucaena leucocephala they observed; $6.28 \mathrm{MJ} / \mathrm{kg} \mathrm{DM}$ of ME, $44.91 \% \mathrm{OMD}$ and $0.37 \mu \mathrm{mol}$ of SCFA. Thus the grass and legume/browse species investigated in the current study have potential to make energy available to ruminants as was also reported in other studies (Ajayi and Babayemi (2008); Yusuf et al., 2013; Tona et al., 2014).

Table 4 In vitro metabolizable energy (ME), organic matter digestibility (OMD) and short chain fatty acids (SCFA) levels

\begin{tabular}{|c|c|c|c|}
\hline Treatments & ME & OMD & SCFA \\
\hline \multicolumn{4}{|l|}{ Grass } \\
\hline P. maximum & $7.07^{\mathrm{a}}$ & $50.67^{\mathrm{a}}$ & $0.70^{\mathrm{a}}$ \\
\hline I. cylindrical & $6.53^{b}$ & $46.69^{b}$ & $0.63^{\mathrm{a}}$ \\
\hline A. fissifolius & $6.09^{c}$ & $44.53^{b}$ & $0.54^{\mathrm{b}}$ \\
\hline B. decumbens & $6.01^{\mathrm{c}}$ & $45.41^{\mathrm{b}}$ & $0.51^{\mathrm{b}}$ \\
\hline \pm SEM & 0.24 & 1.36 & 0.04 \\
\hline \multicolumn{4}{|l|}{ Legume/browse } \\
\hline L. leucocephala & $6.45^{\mathrm{b}}$ & $50.13^{b}$ & $0.49^{b}$ \\
\hline C. pubescens & $10.73^{\mathrm{a}}$ & $78.91^{\mathrm{a}}$ & $1.23^{\mathrm{a}}$ \\
\hline G. sepium & $10.64^{\mathrm{a}}$ & $72.76^{\mathrm{a}}$ & $1.15^{\mathrm{a}}$ \\
\hline \pm SEM & 1.41 & 8.75 & 0.23 \\
\hline
\end{tabular}

\section{Conclusion}

The observed nutritive values of the forages understudied have shown that they could be beneficial for improved goat production in Nigeria. The legume/browse species contained higher amounts of crude protein, ash, enhanced gas production and also, higher predicted metabolizable energy, organic matter digestibility and short chain fatty acids than the grass species. Among the species of grass and legume/browse, the highest 
metabolizable energy, organic matter digestibility and short chain fatty acids values were recorded for Panicum maximum and Centrosema pubescens respectively.

[1] FAO Food and Agricultural Organization. Food and Agricultural Organization of the United Nations. Production year book Vol. 44, (Rome, Italy. 2008) Pp.283.

[2] A. Kamalak, Chemical composition and in vitro dry matter digestibility of leaves of Vitis vinifera. Livestock Research for Rural Development 17 (1), 2005.

[3] F.T. Ajayi, and O.J. Babayemi, Comparative in vitro evaluation of mixtures of Panicum maximum cv Ntchisi with stylo (Stylosanthes guianensis), Lablab (Lablab purpureus), Centro (Centrosema pubescens) and Histrix (Aeschynomene histrix). Livestock Research for Rural Development 20 (6), 2008.

[4] W.L. Evitayani, A. Fariani, I. Ichinohe, and T. Fujihara, Study on nutritive value of tropical forages in North Sumatra, Indonesia, Asian - Aust. J. Anim. Sci. 17 (11), 2004, 1518 - 1523.

[5] S.M. Odeyinka, Effect of feeding varying levels of Leucaena leucocephala and Gliricidia sepium on the performance of West African Dwarf goats, Nig. J. Anim. Prod. 28 (1), 2001, 61-64.

[6] AOAC, Official methods of analysis Association of Official Analytical Chemists, Washington D.C., USA, 2005, Pp. 48.

[7] E.R. Orskov, and I. McDonald, The estimation of protein degradability in rumen from incubation measurements weighted according to the rate of passage, J. Agric. Sci. Camb. 92, 1979, 449-503.

[8] K.H. Menke, and H.Steingass, Estimation of the energetic feed value obtained from chemical analysis and in vitro gas production using rumen fluid, Anim. Res. Dev. 28, 1988, $7-55$.

[9] G. Getachew, H.P.S. Makkar, and K. Becker, Stoichiometric relationship between short chain fatty acid and in vitro gas production in presence and absence of polyethylene glycol for tannin containing browses, FAAP satellilite symposium gas production: Fermentation kinetics for feed evaluation and to assess microbial activity, August $18-19$ Wageningen, Netherlands, 1999.

[10] S.A.S. Statistical Analysis Systems, Institute Inc., SAS/ STAT. User's guide version 6. $3^{\text {rd }}$ Ed.Cary. (North Carolina, USA, 2000).

[11] O.J. Babayemi, In vitro fermentation characteristics and acceptability by West African dwarf goats of some dry season forages, Afr. J. Biotech. 6 (10), 2007, 1260-1265.

[12] K.O. Yusuf, O.A. Isah, O.M. Arigbede, A.O. Oni, and C.F.I. Onwuka, Chemical composition, secondary metabolites, in vitro gas production characteristics and acceptability study of some forage for ruminant feeding in South-Western Nigeria, Nigerian J. Anim. Prod. 40 (1), 2013, 179- 190.

[13] V.O. Asaolu, S.M. Odeyinka, R.T. Binuomote, J.A. Odedire, and O.J. Babayemi, Comparative nutritive evaluation of native Panicum maximum, selected tropical browses and their combinations using in vitro gas production technique, Agric. Biol. J. N. Am. 5 (5), 2014, $198-208$.

[14] G.O. Tona, Investigation of proximate composition and in vitro fermentation characteristics of Panicum maximum, Gliricidia sepium with cassava peels as feed for ruminants in Nigeria, Int. J. Current Microb. Appl. Sci. 3 (10), 2014, 188-197.

[15] B.W. Norton, The nutritive value of tree legumes. In: Forage tree legumes in Tropical Agriculture Gutteridge, R.C. and Shelton, H.M. (Eds.) CAB International, Wallingford, U.K., 1995, 177 - 191.

[16] D.P. Poppi, and S.R. McLennan, Protein and energy utilization by ruminants at pasture, J. Anim. Sci., 73, 1995, $278-290$.

[17] F.S. Nuoala, O.O. Akinbamijo, A. Adewumi, E. Hoffman, E.S. Muetzel, and K. Becker, The influence of Moringa oleifera leaves as substitute to conventional concentrate on the in vitro gas production and digestibility of groundnut hay, Livestock Research for Rural Development 18 (9), 2006

[18] V. Fievez, O.J. Babayemi, and D. Demeyer, Estimation of direct and indirect gas production in syringes: a tool to estimate short chain fatty acid production requiring minimal laboratory facilities, Anim. Feed Sci. Tech. (123 - 124) 2005, 197-210.

[19] K. Sommart, P. Parker, P. Rowlinson, and M. Wanapat, Fermentation characteristics and microbial protein synthesis in in vitro system using cassava, rice straw and dried ruzi grass as substrates, Asian-Austr. J. Anim. Sci. 13, 2000, 1084-1093.

[20] O.J. Babayemi, and M.A. Bamikole, Effects of Tephrosia candida DC leaf and its mixtures with guinea grass on in vitro fermentation changes as feeds for ruminants in Nigeria, Pak. J. Nutr. 5 (1), 2006, $14-18$.

[21] O.J. Babayemi, D. Demeyer, and V. Fievez, In vitro fermentation of tropical browse seeds in relation to their content of secondary metabolites, J. Anim. Feed Sci. 13 (1), 2004, 31 - 34.

[22] G.O. Tona, R.T. Binuomote, and O.J. Babayemi, Evaluation of proximate composition and in vitro fermentation characteristics of Panicum maximum, Gliricidia sepium and wheat bran mixtures as feed for ruminants in Nigeria, Int. J. Food, Agri. Vet. Sci. 4 (2), 2014, 168-175. 